\title{
Challenges and Opportunities to Implement Inclusive Education
}

\section{Wondwosen Mitiku, Yitayal Alemu, Semahegn Mengsitu}

Special Needs Education, University of Gondar, Ethiopia

Volume 1, Number 2/2014

DOI:

Licensed:

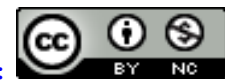

Source of Support: Nil

Conflict of Interest: None declared

Email for correspondence:

mitikuwondwosen@yahoo.com

\section{ABSTRACT}

This study is conducted in order to assess the challenges and opportunities to implement inclusive education in selected primary schools of North GondarZone. In order to attain the objectives of the study, related literatures on international policies and concepts of inclusive education was reviewed in detail. Concerning the significance of the study it is expected that it will highlight those concerned individuals on the existing situation prevailing in connection with the problem under study and devise mechanisms for addressing the observed situation. The study used descriptive survey as a research design to explain the current trends existing in the study area. . As to the samples considered for the study, because there are only two schools it appeared manageable to take them as they are. In regards to participants of the study seventy one participants, namely 4 from the school's principals, 16 from the professional teachers in special needs, and 51 students with different disabilities were involved as sample participants. These samples were taken by using systematic random sampling to give fair and equal chance of selection. With regard to data gathering instrument, questionnaire, structured interview and observation were used to collect data from the participants. The finding roughly show that even though there are some opportunities that support inclusive education it cannot be taken as a guaranty due to lack of awareness, commitment, and collaboration. And there are real challenges that hinder the full implementation of inclusive education. Generally it can be conclude that the challenges outweigh the opportunity on the full implementation of inclusive education and there should be strong collaboration among stakeholders, NGOs, and the concerned bodies in order to realize the journey towards inclusive education.

Key words: Inclusive Education, Special Needs Education, Ethiopia

\section{INTRODUCTION}

Inclusive education means welcoming all children, without discrimination into regular or general schools. By the change of attitude against differential treatment of education differences in people will likely be seen in a positive perspective. It calls for a respect of difference and celebration of diversity. (Disability in Ethiopia, 2005) 
It is not only accommodating children in the regular or general school rather it goes beyond that. For this, the same author said that "It is a focus on creating environments responsive to the differing developmental capacities, needs and potentials of all children. (Disability in Ethiopia, 2005)

Inclusion is not just about placing students with disabilities in to mainstream classrooms. It recognizes that all children have individual needs, and that teachers who are trained to facilitate an inclusive classroom, can better meet the needs of all children (Tomlinson, 1996).

Therefore, from the cited text we can understand that it is a shift in service from simply trying to fit the child into "normal setting", to trying to change the system of education to accommodate the child.

Generally, the concept and practical move needs to be applicable in schools in Ethiopia because our country is not free from the practice of educational exclusion, particularly for people with disabilities, therefore this paper deals with the challenges and opportunities to provide inclusive education in our school system.

\section{Statement of the Problem}

The title is chosen because these schools are on the way to exercise inclusive education in Gondar area and have well trained and experienced teachers who took training about Special Needs Education. Considering all these, these schools are expected to strive for the realization of the provision of inclusive education based on international agreements. Therefore, the schools seem a perfect spot to display the challenges and opportunities for the provision of inclusive education in Ethiopia.

\section{Significance of the Study}

Nature doesn't give a guarantee to live without disability throughout peoples' life span. Disability or defect in physical ability can happen at any time because of natural calamities like earthquake and flooding, or manmade calamites like car accidents, air plane crash or other. These accidents are unconditional and happen without criteria as rich/poor, educated/illiterate, or others. Therefore, any kind of service provision needs to consider disability. Among the services education is one, and primary level education is the focal point of this paper. And conducting a research in this area may have the following significance.

- The finding will clearly indicate the challenges and opportunities for the provision of inclusive education in Gondar schools.

- It will alarm the administrators to think about what could be constructed in schools to accommodate people with different disabilities.

- Even though Ethiopia is a signatory of different international agreements for fair education for all, it seems not practical. Therefore, the study may serve as something pushing to realize inclusive education by identifying the existing challenges and opportunities.

\section{Objective of the study}

Assessing the practical challenges and opportunities for the provision of inclusive education in Chilga and Tikil Dingay primary schools was the general objective of this study. The research will have the following specific objectives, to:

- $\quad$ Check the implementation of inclusive education in the schools.

- Identify the practical opportunities for the provision of inclusive education in the schools.

- Identify the practical challenges to apply inclusive educational system in these schools. 
- To suggest possible solutions by comparing the opportunities and challenges for the provision of inclusive education in this schools.

\section{Research Question}

The research is expected to answer the following basic questions.

- How did teachers of this school implement inclusive education?

- What are the best opportunities for the realization of inclusive education in these schools?

- What are the practical challenges for the provision of inclusive education in these schools?

- What mechanisms should be devised to alleviate these challenges?

\section{Scope of the Study}

The idea and practice of inclusive education is not limited to schools of Gondar zones. It rather has a strong position in developed countries. It has also got national and international legal agreement. However, due to limitation in time, materials, and financial resources, this research is delimited to assess the information in the research topic only in Chilga and Tikil Dingay primary schools.

\section{Study Area and Period}

This study was conducted in Gondar particularly, in Chilga and Tikil Dingay primary schools which are located in Gondar zone, and the study has conducted from August 1, 2012-Jan.30, 2013.

\section{Conceptual Framework}

Inclusion is becoming the ruling principle in the 21st century and the concept of inclusive education is becoming the best means to allow each and every child to involve in the system of education regardless of differences in terms of disability, sex, religion, ethnicity and other (Enabling inclusive education challenges and dilemmas, 2007).

Therefore, having this concept in mind, I am urged to conduct research on the challenges and opportunities for the implementation of inclusive education in Chilga and Tikil Dingay primary schools.

Inclusive Education: is a shift of emphasis on the task of persons providing educational services to make sure that the educational settings were adjusted to accommodate the special educational needs rather than trying to make the children with disabilities fit into the given educational settings. (Inclusive education, 1995)

Inclusive education means: a shift in services from simply trying to fit the child in to "normal settings"; it is a supplemental support for their disabilities or special needs and promotes the child's overall development in an optimal setting (Evans, 1998). It has to include a consideration of overall organization, curriculum and classroom practice, support for learning and staff development (Ainscow, 1997).

Special Needs Education: is an education system that aims at all children and young people of the world, with their individual strengths and weakness, with their hopes and expectations, have the right to education. It is not the education systems that have a right to certain types of children. Therefore, it is the school system of a country that must be adjusted to meet the needs of all children (Bridge \& Moss, 1999).

\section{REVIEW OF RELATED LITERATURE}

While reviewing related literatures, I have browse internet and seen a paper presentation by Susie miles in a symposium on Development Policy entitled "children with disabilities and convention on right of the child". 
The symposium was in Gustart, Stresemann institute, Bonn, Germany, and different people presented their research paper in the scope of "enabling inclusive education:challenges and Dilemmas" from Oct. 27-29/2000.

In the presentation Mile's focus area were disabled girls and children with learning difficulties from the perspective of violating international rights of people to be educated and she said, "... Chosen group of children are arguably the most overlooked and excluded, it is a form of exclusion with in inclusion".

She referred the Salamanca statement of UNESCO-1994 and the 1948 universal declaration of human rights for the realization of inclusive education.

As a researcher her legal reference attracted me to see this research paper from that perspective and identifying the challenges and opportunities in Chilga and Tikil Dingay primary schools taking these institutions as part of the international agreement signatory of Ethiopia.

\section{INCLUSIVE EDUCATION FROM LEGISLATION PERSPECTIVES}

According to Susie miles in her presentation in the symposium every discussion of inclusion is not out of international agreements particularly the Salamanca statement. She said:-

"Any discussion about the definition of inclusive education needs to use the Salamanca statement and framework for action/UNESCO-1994/ as a reference point. The statement re-affirms the right to education of every individual, as enshrined in the 1948-universal declaration of Human rights and renews the pledge made by the world community at the 1990, world conference of education for all to ensure that right is for all, regardless of individual differences. (Enabling inclusive education challenges and dilemmas, 2007).

Furthermore she traces details from Salamanca statement, “... The statement also mentions the 1993 UN standard rules on equalization of opportunities which states that the education disabled children should be an integral part of the education system." (Enabling inclusive education challenges and dilemmas, 2007)

But finally she adds that we don't refer the convention on the rights of children.

The above idea of Salamanca statement is consolidated by Professor Tirussew in his book of Disability in Ethiopia, issues, insights and implication

"In favor of the move towards the inclusive approach, the Salamanca statement and frame work for action on special needs education (UNESCO, 1994) provides the clearest and most unequivocal call in its article 2 and 7 respectively."

Article 2 states:

"... that ordinary school should accommodate all children, regardless of their physical, intellectual, emotional, social, linguistic on other requirements. It further states that all educational policies should stipulate that children with disabilities attend their neighborhood school." (Disability in Ethiopia, 2005)

Article 7 also states:

"... that all children should learn together, whenever possible, regardless of any difficulties or differences they may have. Inclusive schools must recognize and respond to the diverse needs of their student's accommodating both different styles and rates of learning and ensuring quality education to all through appropriate curricula, organizational arrangements, teaching strategies, resource use and partnership with communities." (Disability in Ethiopia, 2005)

Furthermore, another book traces and give due attention for the right of a child to get education access based on the 1990 world conference of education for all.

"Every child has a fundamental right to education and must be given the opportunity to achieve and maintain on acceptable level of learning and every child has unique characteristics, interests, abilities and learning needs." (Strategies to promote to inclusive practice, 2003) 


\section{Principles of Inclusive Education Service}

The following principles briefly give hints about inclusive education and try to show even the scope that inclusive education touches, from the accommodated child to the general community through parents' representation and government bodies.

From interest and right point of view the principle states that:

"Inclusion is the process by which schools, local education authorities, and others develop their cultures, policies and practices to include pupils." (Strategies to promote inclusive practice, 2003).

So, all children should have access to an appropriate education that affords them the opportunity to achieve their personal potential and the interest of children must be safe guarded.

From the responsibilities and service point of view the principles state that:

"With the right training, strategies and support nearly all children with special educational needs can be successfully included in main stream education. And an inclusive education service offers excellence choice and incorporates the view of parents and children." Therefore, Schools, local education authorities and others should actively seek to remove barriers to learning and participation." (Strategies to promote inclusive practice, 2003)

\section{OpPortunities AND CHALLENGES OF INCLUSIVE Education}

\section{Opportunities of Inclusive Education}

"It provides students with disabilities access to students without disabilities access to curricula and textbooks to which most other students are exposed" (Disabilities in Ethiopia 2005)

"It developed out of a strong belief in human rights and social justice, it perceive separate special education as dehumanizing, labeling, ineffective and expensive /disability in Ethiopia 2005).Generally, some the opportunities to provide inclusive education in Ethiopia context includes:

A) The Constitution of FDRE

The Constitution of Federal Democratic Republic of Ethiopia (FDRE, 1995), under article 9 stipulates that all international agreements ratified by Ethiopia are an integral part of the law of the land. It has also elaborates that all legislative, executive and judicial organs have the responsibility to respect and enforce what is embodied under that section, which should be done in conformity with human rights considerations.(Art.9:4). This reveals that all international agreements that have been ratified by the country should be implemented and the conserved bodies should play an important role for the implementation.

B) The Education and Training Policy

It confirms the importance of early childhood education .it has further confirmed that efforts should be made to enable the handicapped and the gifted learn in accordance with their potential and needs (ETP, 1994). But when we see the practice of our country, there is no effort made to enable them learns according to their needs and potential.

C) The Higher Education Proclamation

According to the higher Education Proclamation No.650/2009 article 40, states that institutions shall make, to extent possible, their facilities and programs amenable to use with relative ease by physically challenged students. It has also clearly stated that students with disabilities shall during their stay in the institution of higher learning, get special support to pursue their education effectively. In addition to these there are also other education related policy documents which promote the implementation of inclusive education such as the Education Sector Development Program (ESDP IV), the Special Needs Education Strategy Program. 


\section{Challenges of Inclusive Education}

"The new challenge to inclusive education is to meet the needs of all children with and without disability in the general classroom. It is not an easy process and requires a lot of struggle and commitment to overcome attitudinal and social barriers". (Disability in Ethiopia, 2005)

"...one of the determinant factors refers to attitudes of the community towards persons with disabilities and inclusion. A limited understanding of the concept of disability, negative attitude towards persons with disabilities and a hardened resistance to change are the major barriers impeding inclusive education.(IDDC,1998) cited in Tirusew.

Generally, according to professor Tirusew, the challenge towards inclusive education could emanate from different directions such as attitudinal factors, resistance to change, rigid school systems and learning environment, lack of clear educational strategies, lack of instructional and learning materials and inadequate budget.

\section{IDENTIFICATION AND SCREENING}

Assessment is a multifaceted process of gathering information by using appropriate tools and techniques in order to make educational decisions about placement and the educational program for a particular child. Appropriate adaptations and modifications must be made available to assure valid and reliable findings. Since children's needs change from month to month and from year to year, regular periodic assessment must be conducted.

\section{Individualized Educational Plan}

After the child's needs have been assessed and determination of eligibility for special education services has been made, the staffing team is responsible for the development in writing, and maintenance of an individualized educational plan (IEP). The Individualized Educational Plan is the primary document that outlines specific plans for the eligibility process and any further information collected by multidisciplinary specialists and by both special and regular teachers can assist with the development of the Individualized Educational Plan. Realistically, the special education teacher will have to conduct further curriculum based assessments to gather the types of instructionally useful data to be able to develop appropriate goals and objectives and to know where to begin instruction (Smith, 1990). The IEP then details the least restrictive, most appropriate placement and oiliness the instructional program. The Individualized Educational Plan must be evaluated and then rewritten annually as long as service are still necessary. The major components of the Individualized Educational Plan include statement of current level of performance, annual instructional goals, short-tem objective, and statements detailing the special services to be provided and the degree of integration in the regular classroom, schedules for initiation and evaluation of services.

\section{The Physical Environment Of Learning For Students With Special needs}

The physical environment (classroom layout and appearance, classroom arrangement, furniture arrangement etc) contribute a lot to promote active-learning method. According to Dilnesaw (2009), the physical environment in a classroom can challenge active-learning. According to him there should be adequate well-maintained and furnished classrooms to effectively conduct teaching-learning process. Therefore the place where the child is positioned in the class, the way the classroom materials are arranged, the effects of sound environment and the condition of a building play a vital role in enhancing or retarding the teaching-learning process of visually impaired children. 


\section{Teaching Methods And Procedures}

Method in general means a particular order imposed up on teaching or presentation of activities. It refers to the construction of how teaching ought to be done. Methods are means of conveying ideas and skills to impart and acquire a certain subject matter in more concerted and comprehensive way.

Methods describe conceptually the instructional process, that is not only how information gets from the teacher to the learner but also how the learner, use it, interact with it, receives guidance and is given feedback. No learning can occur if the students passively sit. The student must actively respond; must participate. Because education is a human experience acquired in the process of mans interaction with his physical, and social environment. Basically, method in teaching concerns the way teachers organize and use techniques of teaching, subject-matter, teaching tools, and teaching materials to meet teaching objectives. It consists of formulating the goals and objectives for teaching, selecting the subject matter and the teaching procedures, evaluating the success of the learning activates, and following up their success and failure.

\section{Research Design and Methodology}

\section{RESEARCH DESIGN}

It is a survey study in Chilga and Tikil Dingay primary schools and I preferred a survey study because, the issue of inclusive education is not only the concern of Chilga and Tikil Dingay primary schools but all school systems in the nation, but the study conducted at Chilga and Tikil Dingay schools can serve as a model study for other schools and being it is survey, we can made reference or generalization for a large number of population.

\section{SAMPLE SIZE AND SAMPLING TeChNiQueS}

Being it is a survey study, I know that the samples or participants shouldn't be less than thirty, therefore thirty participants will be selected from 3 categories of each school that are professional teachers in the area of special needs education, students with different disabilities, school's principals and "students with out disability". Therefore, the sampling size will be the following.

- Four principals of the schools.

- Sixteen teachers who teach in inclusive class rooms.

- Thirteen deaf students, who are learning in sign language.

- $\quad$ Eight students with visual impairment.

- Sixteen students with physical/motor disability.

- Fourteen students intellectual disability.

Regarding the sampling techniques stratified available sampling will be involved because three strata are found for professional teachers, school's principals, students with disability. As a specific sampling technique, I will use one of the sub groups of purposive sampling which is expects sampling for the principals and professional teachers because their response as a data is more reliable and valid, since they are expect in the area.

For the rest of participants/ visually challenged, physically challenged and deaf students and students with intellectual impairment/ I will select all of them by available sampling method because the number of these students are small in each strata or category. 


\section{DATA COLLECTION}

The instrument I prefer to collect data from students' participants is questionnaires and the questionnaire contains both close ended and open ended questions. I preferred questionnaires because all the participants are literate and able to put their idea on a paper and they can fill that at the time they feel comfortable either at home or a somewhere else they like. For the sake of triangulation I will use interview for the principals and teachers and un structured observation will be held.

\section{ANALYSIS PLAN}

To analyze the data, description for open ended questions, structured interview, and observation and statistical expression, percentage, and tabular presentation for the close ended questions will be used to present the research report.

\section{Research Procedures}

As a procedure due attention will be given to all categories of participants because being inclusive education touches everybody, each group represents part of society in their respective part. To distribute the questionnaires, hardcopy will be prepared considering the number of participants and concerning questions to each group and the researcher will reach to each participants personally and will take appointment to collect because they can fill it at home within the range of two to three days.

This may give them ample time to fill it with due attention, being they are professionals and students they may not have time to fill the paper in a time less than two days, therefore, giving them ample time may increase the authenticity of their response.

For the ten visually handicapped participants, the researcher will fill the questionnaires by reading each question for them if they are willing and if they have no one to do that for them.

\section{Ethical Consideration}

Participants' economic background, ethnicity, sex or race as means of identify will not be considered because all these have nothing to do with the idea of the research and inclusive education disregards these issues. But during question formulation and personal contact to give them the questionnaires, care will be taken not to heart them unintentionally because of their sensitive part of disability and as a neutral researcher, in no way discrimination will be manifested between the so called "normal" and students with disability.

\section{DATA PRESENTATION AND ANALYSIS}

\section{ANALYSIS OF BACKGROUND INFORMATION}

This chapter presents the interpretations of the data gathered from the participants of students with different impairments, principals, and teachers that was gathered through a questionnaire, interview and observation. In analyzing the data both quantitative and qualitative method was employed as a technique. The data collected through interview and observation have completely analyzed and presented qualitatively and The data collected through questioner are presented in tables and percentages. Following each table interpretations of data are presented in detail. 
Table 1: Background Information of the Student Participants of the Study (No. $=49$ )

\begin{tabular}{|c|c|c|c|c|c|c|}
\hline S.No. & Items & & \multicolumn{2}{|c|}{ Serako Primary School } & \multicolumn{2}{|c|}{ Selam Ber Primary school } \\
\hline \multirow[t]{4}{*}{1} & \multirow[t]{4}{*}{ Sex } & & Frequency & Percentage & Frequency & Percentage \\
\hline & & Male & 15 & 60 & 10 & 38.5 \\
\hline & & Female & 10 & 40 & 16 & 61.5 \\
\hline & & Total & 25 & 100 & 26 & 100 \\
\hline \multirow[t]{4}{*}{2} & \multirow[t]{4}{*}{ Age } & $8-10$ years & 5 & 20 & 6 & 23 \\
\hline & & $11-13$ years & 12 & 48 & 10 & 38.5 \\
\hline & & $14-16$ years & 8 & 32 & 10 & 38.5 \\
\hline & & Total & 25 & 100 & 26 & 100 \\
\hline \multirow[t]{5}{*}{3} & \multirow{5}{*}{$\begin{array}{l}\text { Type of } \\
\text { Disabilities }\end{array}$} & Visual Impairment & 4 & 16 & 4 & 15.4 \\
\hline & & Hearing Impairment & 9 & 36 & 4 & 15.4 \\
\hline & & Intellectual Impairment & 7 & 28 & 7 & 26.9 \\
\hline & & Physical Impairments & 5 & 20 & 11 & 42.3 \\
\hline & & Total & 25 & 100 & 26 & 100 \\
\hline \multirow[t]{5}{*}{4} & \multirow[t]{5}{*}{ Grade } & $1^{\text {st }}$ & 5 & 20 & 5 & 19.2 \\
\hline & & $2^{\text {nd }}$ & 6 & 24 & 11 & 42.3 \\
\hline & & $3^{\text {rd }}$ & 6 & 24 & 5 & 19.2 \\
\hline & & $4^{\text {th }}$ & 8 & 32 & 5 & 19.2 \\
\hline & & Total & 25 & 100 & 26 & 100 \\
\hline
\end{tabular}

As table 1 indicates, fifteen $(60 \%)$ and ten (38.51) of responds of Serako primary school and Selam ber Primary School were female respectively. While Serako Primary school has ten $(40 \%)$ and selamber primary has sixteen $(61.5 \%)$ female participants. When we see the age of participants of Serako Primary School, five (20\%) are 8-10 years, 12(48\%) are 11-13 years and $8(32 \%)$ are $14-16$ years. Selamber Primary School has $6(23 \%)$ of $8-10$ years, $10(38.5 \%)$ of 14-16 participant students with special needs.

Additionally, in Serako Primary School there are 4(16\%), 9(36\%), 7(28\%), 5 (20\%) participants of visual impairment, Hearing impairment, intellectual impairment and other impairments respectively. Whereas selamber primary school has $4(154 \%), 7(26 \%)$ and $11(42.3 \%)$ of participants of visual impairment, hearing Impairment, intellectual impairment and other impairments respectively. When we analyze the grades of participants of serako Primary school 5(20\%) are 1st grade, 6(24\%) are 2nd grade, $6(24 \%)$ are 3rd grade and 4 th grade students are 8(32\%). Similarly Selamber School has 5 (19.2\%) 1st grade, 11 (42.3\%) 2nd grade, $5(19.1 \%)$ 3rd grade and $5(19.2 \%)$ 4th grade participants.

From this we can inferred that in serako primary school most participants were male. In contrary selam ber primary school has high number of female students with special needs. In both schools, most students are in the age range of 11-13 year. In Serako primary schools, most students have hearing problem and in selam ber primary students most students have intellectual impairment. Most students are in 4th grade in serako primary school and 2nd grade in selam ber primary school.

\section{ANALYSIS OF QUESTIONNAIRE RESULTS}

Table 2. Results Obtained from Questionnaires Filled out by Student Participants of the Study $($ No. $=49)$

\begin{tabular}{|c|c|c|c|c|}
\hline \multirow[t]{2}{*}{ S. No } & \multirow[t]{2}{*}{ Items } & \multicolumn{3}{|c|}{ Responses } \\
\hline & & & Frequency & Percentage \\
\hline \multirow{3}{*}{1} & \multirow{3}{*}{$\begin{array}{l}\text { Is the school compound comfortable for } \\
\text { students with disabilities? }\end{array}$} & Yes & 4 & 8.2 \\
\hline & & No & 45 & 91.8 \\
\hline & & Total & 49 & 100 \\
\hline \multirow[b]{2}{*}{2} & \multirow[b]{2}{*}{ Are the classrooms accessible for students } & Yes & 10 & 20.4 \\
\hline & & No & 39 & 79.6 \\
\hline
\end{tabular}


Asian Journal of Humanity, Art and Literature, Volume 1, No 2 (2014)

\begin{tabular}{|c|c|c|c|c|}
\hline & with disabilities? & Total & 49 & 100 \\
\hline \multirow[t]{3}{*}{3} & \multirow{3}{*}{$\begin{array}{l}\text { Does the school community believe on the } \\
\text { inclusiveness of students with disabilities } \\
\text { with other students? }\end{array}$} & Yes & 6 & 12.2 \\
\hline & & No & 43 & 87.8 \\
\hline & & Total & 49 & 100 \\
\hline \multirow[t]{3}{*}{4} & \multirow{3}{*}{$\begin{array}{l}\text { Does students with disabilities stigmatized } \\
\text { by those students without disabilities? }\end{array}$} & Yes & 12 & 24.5 \\
\hline & & No & 37 & 75.5 \\
\hline & & Total & 49 & 100 \\
\hline \multirow[t]{3}{*}{5} & \multirow{3}{*}{$\begin{array}{l}\text { Do students without disabilities participate } \\
\text { in different activities of the school? }\end{array}$} & Yes & 14 & 28.6 \\
\hline & & No & 35 & 71.4 \\
\hline & & Total & 49 & 100 \\
\hline \multirow[t]{3}{*}{6} & \multirow{3}{*}{$\begin{array}{l}\text { Does the school community give special } \\
\text { service for students with disabilities? }\end{array}$} & Yes & 5 & 10.2 \\
\hline & & No & 44 & 89.8 \\
\hline & & Total & 49 & 100 \\
\hline \multirow[t]{3}{*}{7} & \multirow{3}{*}{$\begin{array}{l}\text { Are the school's leisure places, toilet rooms, } \\
\text { classroom gets, and others accessible to } \\
\text { those students with disabilities? }\end{array}$} & Yes & 12 & 24.5 \\
\hline & & No & 37 & 75.5 \\
\hline & & Total & 49 & 100 \\
\hline \multirow[t]{3}{*}{8} & \multirow{3}{*}{$\begin{array}{l}\text { Is the sport field of the school comfortable to } \\
\text { those students with disabilities? }\end{array}$} & Yes & 14 & 28.6 \\
\hline & & No & 35 & 71.4 \\
\hline & & Total & 49 & 100 \\
\hline \multirow[t]{3}{*}{9} & \multirow{3}{*}{$\begin{array}{l}\text { Do students with disabilities interact with } \\
\text { those students without during break and } \\
\text { entry time? }\end{array}$} & Yes & 18 & 36.7 \\
\hline & & No & 31 & 63.3 \\
\hline & & Total & 49 & 100 \\
\hline \multirow[t]{3}{*}{10} & \multirow{3}{*}{$\begin{array}{l}\text { Is there adapted curriculum for students } \\
\text { with special needs? }\end{array}$} & Yes & 3 & 6 \\
\hline & & No & 46 & 94 \\
\hline & & Total & 49 & 100 \\
\hline \multirow{3}{*}{11} & \multirow{3}{*}{$\begin{array}{l}\text { Is the teaching methodology of teachers' } \\
\text { comfortable for students with special needs? }\end{array}$} & Yes & 8 & 16.3 \\
\hline & & No & 41 & 83.7 \\
\hline & & Total & 49 & 100 \\
\hline \multirow{3}{*}{12} & \multirow{3}{*}{$\begin{array}{l}\text { Is the assessment methodology of teachers' } \\
\text { comfortable for students with special needs? }\end{array}$} & Yes & 8 & 16.3 \\
\hline & & No & 41 & 83.7 \\
\hline & & Total & 49 & 100 \\
\hline
\end{tabular}

As indicated in table 2, the questionnaire conducted in serako and selam ber primary schools revealed many results. The above mentioned table shows that many respondents of students agree that the school compound is not comfortable for students with disabilities. $45(91.8 \%)$ students assured that the school compound is not comfortable for students with disabilities. Only $4(8.2 \%)$ of respondents responded that the school compound is comfortable for students with disabilities. Most respondents agree that the school's classrooms are not accessible for students with disabilities. As we observe from the above mentioned table 39(79.6\%) of students assured that the classrooms are not accessible for students with disabilities. Whereas 10(20.4\%) of respondents said that the classrooms are accessible for students with disabilities.

Many respondents agree that the school community did not believe on the inclusiveness of students with disabilities with other students. $43(87.8 \%)$ of students responded that the school community did not believed on the inclusiveness of students with disabilities with other students. In the other side, 6(12.2\%) of respondents responded that the school communities with other students. And also most students with disabilities are stigmatized by those students without disabilities. Most students of the respondents 37(75.5\%) evidenced that students with disabilities are stigmatized by students without disabilities. Whereas 12(24.5) of respondents responded that the students disabilities are stigmatized by students without disabilities. Most respondents agree that students without disabilities did not participate in different activities of the school. 35(71.4\%) of students responded that students with disabilities did not participate in different activities of the school. For the same question, $14(28.6 \%)$ of respondents responded that students with disabilities are participated in different activities of the school.

As can be seen from the table 2, almost all respondents $44(89.8 \%)$ of students responded that the school community did not give special service for students with disabilities. On 
the other hand $5(10.2 \%)$ of respondents believed that the school community gave special service for students with disabilities. The school leisure place, toilet rooms, classroom gets, and other things are not accessible to those students with disabilities. That is, 37(75.5\%) of respondents evidenced that the school leisure place, toilet rooms, classroom gets are not accessible to students with disabilities. Whereas $12(24.5 \%)$ of students responded that the schools leisure please, toilet rooms, classroom gets are accessible for students with disabilities. And also, the sport field of the schools are not comfortable to those students with disabilities.35(71.4\%) of respondents said that the sport field of the school is not comfortable to students with disabilities and 14(28.6\%)of them agreed that, the school sport fields are comfortable for students with different kinds impairments. Most students with disabilities $31(63.3 \%)$ did not have interaction with students without disabilities during break and entry time. But $11(22-4 \%)$ of students with disabilities have interaction with students without disabilities during entry and Break time.

When we come to the education life of students with special needs, they have not adapted curriculum and individualized education program, the teaching methodology is not comfortable and generally the assessment methodology is not also comfortable for those students with special needs. This is evidenced with that almost all respondents 46 (94\%) confirmed that there are no adapted curriculum for students with special needs. In contrary, $3(6 \%)$ of students agreed on the presence of adapted curriculum for students with special needs. Similarly $41(83.7 \%)$ of respondents agreed that the teaching methodology is not comfortable for students with special needs. But only $8(16 \%)$ of students have said that, the teaching methodology of teachers are comfortable for students with special needs. The assessment methodology of teachers is not comfortable for $41(83 \%)$ of respondents and comfortable for $8(16.3 \%)$ of respondents. These show that teachers do not use appropriate teaching methods that address the needs of students with special needs and they did not modify the assessment methods according to the needs and potential of students with special needs.

\section{Presentation of Data Obtained Through Interview}

\section{INTERVIEW REPORT FROM SCHOOL PRINCIPALS}

\section{Regarding the opportunity they have to implement inclusive education}

they replied as they know Some declaration and international agreement that gave special attention for the education of students with special needs like Education for all, UN convention on the right of the child but these declarations and agreements have nothing on our country's education system and the only opportunity we have is the support we got from NGOs like save the children Norway and CBR workers. Concerning the challenges they faced they said that there are many challenges that hinder the implementation of inclusive education such as the attitude of teachers and parents towards children with disability and teachers of students with special needs, lack of attention from the education office both zones and woreda, lack of educational materials, large class size, etc.

\section{Regarding the process of identification and assessment}

Principals were asked whether the school has eligibility criteria to admit children with special needs or not. They replied that the school does not have multidisciplinary team to determine eligibility of children for special education service. But we admit children who have vision, hearing, and other problem and who are from poor families. In addition to 
this the community based rehabilitation workers help the school in searching children who have different types of disability and make them to be enrolled in the school.

The other question was raised to know the process of identification and assessment the school used for children with special needs, principals of both schools responded that to identify children with visual impairment, the CBR workers conduct an observation on outreach based support and detect those children whom they suspects of having visual problem. In this process they observe different signs which are displayed by the children. These include red eyes, watery eyes, crossed eyed etc. they added that after identifying the child with vision problem they did not conduct assessment procedures to check whether the suspected vision problem exactly exist or not which include: distance vision test using E-chart, measuring field of vision, color vision test etc. Regarding periodic assessment, the school does not conduct any periodic assessment after children have started their education. Another attempt was made to know whither teachers use IEP or not, principals of chilga responded that teachers tries to use IEP buy it is not at the level to be expected and they do not give due attention. Principals of Tikil dingay responded that teachers do not use IEP because in this school children with special needs have integrated with the other students and they are few in number, therefore it is not necessary for teachers to prepare an IEP and they can address each individual's needs without preparing on IEP.

\section{Regarding the availability of adequate special educational materials and equipment}

Question concerning the availability of special materials and equipment and library services, they said that there is no reference books written in Braille, and other necessary special educational materials and equipment in the library. But in Chilga School there are adequate slate and stylus, abacus and Braille paper in the store and students do not have a chance to use these materials because teachers of the school do not have adequate skill to manipulate these materials. Regarding the conduciveness of the physical environment, the principles reported that the compound is not suitable enough for students who uses wheelchair and students with visual impairment and it can hinder the teaching learning process to some extent. Therefore they said that the school has a plan to adjust the physical environment of the compound in order to make it suitable for students with different disability fence. Finally they were asked about the interaction between teachers and students with special needs in classrooms and outside the classroom.

\section{INTERVIEW REPORT FROM TEACHERS}

Regarding the teaching strategy used to address the needs of students with special needs

Teachers were asked about the teaching method they commonly used, they replied that they used different method that they believe effective based on the type of lesson presented. They used group discussion, pair-work, lecture method to make students active participant and involve in different activities. During the observation session the researcher has also observed that teachers tried to use different methods to involve all students in each activities and to make them active participants.

They were also asked whether they give additional time for students with special needs to do their activities, they replied that they didn't give any additional time for them in the regular class because of time limitation but students have ample time in the resource room to do different activities. Therefore there is no trends and practice of giving additional time different from other students.

Another attempt was made to know whether there is any alternative teaching procedures teachers used to help students with special needs, they said that sometimes they tire to 
slow their speed while they present the lesson in order to help these students follow the lesson and understand it clearly. And they also tire to write in bold on the blackboard to help students with low vision become independent in their reading.

The other question was raised to get feedback whether teachers use individualized education plan /IEP/ for students with special needs they said that there is no trends and practice to prepare individualize educational plan for students with special needs because the school's expectation is the same for all students. And therefore there is no need to use IEP.

\section{Regarding the availability of adequate special educational materials and equipment}

Another question was raised to know about the adequacy of the resource room to support students with special needs, they said that although it has abacus, slate and stylus, tape recorder and text books it is not adequate to provide the service needed for these children and most of the time children use the resource room as a library to read their text books and to do additional activities in their free time.

Regarding students' access to library service, they have said that there are no reference materials written in Braille and other supportive materials in the library. Therefore students do not use library and instead they use the resource room as a library.

\section{Regarding the conduciveness of the physical environment}

Concerning the conduciveness of the physical environment for the teaching learning process they respond that the compound is not suitable enough for students who uses wheelchair and students with visual impairment and this may have significant impact in the teaching learning process. Other teacher of Chilga also claimed that the narrowness of the compound might affect the mobility of the students because it is crowded by students during the break time and as a result they prefer to stay on the floor in the break time.

The final question was if they have any recommendation, they recommended that the resource room should be equipped with the necessary materials to provide the service needed for students with special needs and teachers should get in service training to update their knowledge and how to use alternative teaching procedures in order to address the students needs and teach in accordance with their potential.

\section{Data Obtained through Observation}

In order to supplement the information obtained through interview, the researcher made observation on the classroom environment and the resource rooms and the result has presented as follows. The students with special needs are distributed in different grades. In each of the observed grades their numbers varies from 1-6. In most case more than one student with special needs is included and in all case the students with special needs sit together with other peers. Regarding special educational materials, there were no materials observed in the hands of students with special needs as well as the classroom teacher like tape recorder, special teaching aids, measuring devices, geographical aids.

The width of the classroom is not wide enough to allow visually impaired students to move freely in the classroom and there is a little gap between rows of desks.

Concurring classroom instruction, all teachers in the observed class tries to use different teaching strategies like group work, par work to involve students with special needs in all activities. But teachers do not give additional time to complete class work and do not use other alternative teaching strategies to support students with special needs.

The resource room lack some necessary special educational materials and equipment like reference written in barillas geographical aids and measuring devices. And in one of the 
school (Chilga) the available materials are putted in the store due to lack of skilled man power and students do not have opportunity to access these materials.

\section{Discussion}

As indicated in the finding principals of both schools said that they know about some of the opportunities such as declaration and international agreement that gave special attention for the education of students with special needs like Education for all, UN convention on the right of the child but they did not take these opportunities as a guarantee to implement inclusive education and the only opportunity they have is the support they got from NGOs like save the children Norway and CBR workers but The Constitution of Federal Democratic Republic of Ethiopia (FDRE, 1995), under article 9 reveals that all international agreements that have been ratified by the country should be implemented and the concerned bodies should play an important role for the implementation.

In addition to this many scholars agreed that there should be a multi-disciplinary team meeting consists of different professionals to determine the child's eligibility for special education service. Tuttle (1981) cited in Scholl (1986) further emphasizes that if a child has demonstrated that he has a visual impairment, then here must be sufficient evidence to indicate that the visual impairment is indeed an educational handicap and that is interfering with the child's adequate functioning in the regular classroom.

To identify children with visual impairment the school conduct an observation on those children. In this process the school observes different signs which are displayed by the children. In fact literature also suggests these and other signs to identify children with special needs. For instant, Gearheart (1988) stated that observable signs which help to suspect a child having visual impairment included: red eye lids, crust or lids among the eyelashes, watering eye or discharges, crossed eye.etc.

In addition the schools do not conduct further assessment to know the degree of the problem and for appropriate educational placement. In contrary to this (Polloway and Patton, 1997) emphasizes the importance of periodic assessment to know the degree of their vision and to change the placement accordingly saying that "since children needs change from month to month and from year to year, regular periodic assessment must be conducted."

Regarding Individualized Educational Plan, as the researcher has observed and interviewed teachers do not have individualized educational plan for students with special needs . But literatures emphasize the importance of Individualized Educational Plan to address the unique needs of each student. Smith stated that the Individualized Educational Plan should include statement of current level of performance, annual instructional goals, short term objectives, statement detailing special services to be provided and the degree of integration in the regular classroom.

Concerning teaching strategies the respondents have explained that teachers used different teaching strategies like group discussion, pair work and lecture method according to the type of the lesson and subject matter. And teachers tries to involve students with special needs in all activities and to make them active participants. In line with this Azeb (1984) said that learning to occur, students must actively participate. No learning can occur if the students passively sit because "education is a human experience acquired in the process of man's interaction with his physical and social environment."

Concerning alternative teaching procedures teachers tried to slow their speed while presenting the lessons in order to help the students follow the lesson and understand it clearly and they also tried to write in bold on the blackboard to support low vision 
students to become independent in their reading. But the concept of alternative teaching procedures for students with special needs is far more from this. Teachers do not give extra time for students with special needs to complete their activities because they think that these students are equal with their peers and do not need additional time. But Heward and Orransky said that regardless of the degree of impairment, one teaching procedure that has been recommended for students with special needs is increased time allotment for task completion. In addition to this the testing procedures are the same other students and it is not modified and adapted for them. Concerning this idea Gearheart has gives great emphasizes by saying "students with special needs require extra time to complete assignments and examination and testing procedures may have to be modified for them. Therefore it may be necessary either to extend the time for completion of the test or to reduce the number of test items."

Regarding materials and equipment all respondents of teachers, students and principals have indicated that although there are Braille writer, and slate and stylus, there is a shortage of Braille atlas, globe, measuring device, reference book written in Braille and other necessary special materials in the library and resource rooms.

Students have also reported that the library does not have enough special educational materials and the situation in the library is not convenient for visual impaired students. It is not well furnished with the necessary materials such as tape recorder, talking books, functioning electric socket. In contrary to this literatures show the importance of adapted and modified materials and equipments Trussew stated that the primary nature of educational program for the visually imparted students involves the modification and adaptation of educational materials such as mathematical aids, geographical aids, writing aids, talking calculator, closed circuit TV etc. Regarding the conduciveness of the physical environment for the teaching-learning process, all participants of the study have reported that the compound is not suitable for students with visual impairment and physical disability. The majority of the students have complained that the width and the surface of the desk is not suitable to use slate and stylus and to accommodate all the stationary and other materials. In relation to this Best (1992) pointed out that the height and the surface of the desk needs to be larger, flatter and more sloping to accommodate all Braille and printed materials and equipments. The place where the visually impaired students positioned in the classroom is comfortable for them. As they explained in the interview part and also observed by the researcher in the observation session their usual place is at the front side of the classroom in order to make them listen attentively and to help students with low vision to read what is written on the blackboard in large print. In line with this Best (1992) contends that the position of the blind child should enable him/her to work without any strain and the blind child can better benefit from the learning if they are placed where their attention is not taken up by other external stimuli.

Visually impaired students do not have access to move freely in the classroom. Since the sizes of the classroom are small, the desks are putted very close to each other and the passage between the rows is too narrow and therefore it does not permit free movement. In contrary to this findings best (1992) again explains that the classroom has to give free access which allows the child with visual impairment to move easily in the classroom. 


\section{CONCLUSION}

The main purpose of this study was to assess the opportunities and challenges to implement inclusive education. To this effect, the following basic research questions were formulated to carry out the study.

- How did teachers of this school implement inclusive education?

- What are the best opportunities for the realization of inclusive education in these schools?

- What are the practical challenges for the provision of inclusive education in these schools?

- What mechanisms should be devised to alleviate these challenges?

In order to deal with these basic questions, related literature was properly reviewed and questioner, interview and observation check list were prepared to collect the data. The participants of the study were 6 teachers, 8 students with visual impairment, 13 students with hearing impairment, 14 students with intellectual impairment, 16 students with physical disability and 2 principals of each school. Concerning the sampling technique, purposive and random sampling method were employed to select students, principals and teachers and the data obtained was analyzed both quantitatively and qualitatively.

Based on the above major findings of the study, the following conclusions are made for the opportunities and challenges to implement inclusive education.

- The schools have little opportunities and these opportunities did not pave the way to implement inclusive education. And both schools faced many challenges to implement inclusive education. Some of the challenges to implement inclusive education in these schools are, the attitude of teachers and parents towards children with disability and teachers of students with special needs, lack of attention from the education office both zones and woreda, lack of educational materials, large class size, lack of skilled man power etc.

- The schools do not conduct scientific way of identification and assessment process to identify and assess children with special needs. And there is no periodic assessment to know the degree of their needs.

- The school does not have eligibility criteria to admit students with special needs.

- Teachers do not prepare individualized educational plan (IEP/ for students with special needs though it is important to address the unique needs of each students.

- Although teachers tried to use different teaching strategies to involve students with special needs in all activities, they do not provide extra time to complete their activities, and the testing procedures is not modified and adapted for them.

- There is a shortage of special educational materials and equipment in the library and resource room such as reference books written in Braille and some geographical and mathematical aids. In addition to this the situation in the library is not convenient for students with special needs.

- Visually impaired students are positioned or placed at the front side of the classroom but the width and the surface of the desk is not suitable to use slate and stylus and to accommodate all the stationary and other materials

- Since the classroom is narrow and desks are putted very close to each other, visually impaired students do not have access to move freely in the classroom.

\section{RECOMMENDATION}

Ethiopia has come along a way to education for all, however, there is still a gap in providing access to all children and actualization of inclusive education as a result schools and teachers find it difficult to accommodate students with special needs and compel them to adapt to the school instead of adapting the school to the needs of the students. 
To improve the existing trends and practice of teaching students with special needs and to address the special educational needs of those children, it require the collaborative efforts of parents, community members, teachers, school principals, governmental agencies. With this background, the following recommendations are forwarded.

- The school should involve the scientific ways of identification and assessment procedures and should conduct periodic assessment. Because if the students needs is not fully assessed, it will be very difficult to address all their needs or it might put them inappropriate placement.

- The school should have eligibility criteria to admit students with special needs because having a disability alone do not guarantee special education service.

- Teachers should have to prepare individualized educational plan for students with special needs to become a real inclusive school. Because the real essence of teaching students with diverse educational needs is addressing the unique needs of each students.

- The school should ensure the availability of special materials and equipment by allocating special budget and the library and the resource room should be equipped with the necessary materials to provide the service needed for students with special needs.

- A particular attention should be offered to students with special needs in the procedures of testing and examination. As the first measure, extra time should be allotted. The item should also be modified and the number of items has to be reduced.

- Further practical training should be given for teachers to update their knowledge especially on the area of sign language and Braille.

- The desks need to have wide surface that can contain all the stationary and other materials and suitable to use slate and stylus.

\section{REFERENCES}

Ahmed, A. A. A., Siddique, M., \& Masum, A. A. (2013, May). Online Library Adoption in Bangladesh: An Empirical Study. In e-Learning" Best Practices in Management, Design and Development of e-Courses: Standards of Excellence and Creativity", 2013 Fourth International Conference on (pp. 216-219). IEEE.

Beirne-Smith, M., Patton, J. R., \& Ittenbach, R. (1997). Mental retardation (4th ed.). Columbus, OH: Merrill.

Blumberg, B., cooper, D. R. and schindler, P. S. (2011). Business Research Methods, 3rd European Edition. London, McGraw Hill.

Byrnes, M. (1990). The regular education initiative debate: A view from the field. Exceptional Children, 56, 345-349.

Davis, W. E. (1990). Broad perspectives on the regular education initiative: Response to Byrnes. Exceptional Children, 56, 349-351.

Fuchs, D., \& Fuchs, L. S. (1994-95). Sometimes separate is better. Educational Leadership, 52, $22-24$.

Hilton, A., \& Liberty, K. (1992). The challenge of ensuring educational gains for students with severe disabilities who are placed in more integrated settings. Education and Training in Mental Retardation, 27, 167-175.

Jenkins, J. R., \& Heinen, A. (1989). Students' preference for service delivery: Pull out, in-class, or integrated models. Exceptional Children, 55, 516-523.

Polloway, E. A., \& Patton, J. R. (1997). Strategies for teaching learners with special needs (6th ed.). Columbus, OH: Merrill.

Polloway, E. A., \& Smith, T. E. C. (1992). Language instruction for students with disabilities. Denver, CO: Love Publishing.

Polloway, E. A., Patton, J. R., Epstein, M. H., \& Smith, T. E.C. (1989). Comprehensive curriculum for students with mild handicaps. Focus on Exceptional Children, 21, 1-12.

Sadeghi DB and Safari R. 2012. The Impact of Collaborative Task on the FL Vocabulary Acquisition ABC Journal of Advanced Research, 1, 8-14. 
Smith, J. D. (1995). Inclusive school environments and students with disabilities in South Carolina. Occasional Papers, 1, 1-5.

Smith, T. E. C., Price, B. J., \& Marsh, G. E. (1986). Mildly handicapped children and adults. St. Paul, MN: West Publishing.

Sultana M. 2014. Ethics in Teaching Profession ABC Journal of Advanced Research, 3, 44-50.

This article was adapated, with permission, from Smith, T. E. C., \& Hilton, A. (1994). Program design for students with mental retardation. Education and Training in Mental Retardation and Developmental Disabilities, 29, 3-8.

Tom E. C. Smith is Professor and Associate Dean, University of Arkansas at Little Rock. Carol A. Dowdy is Associate Professor, University of Alabama at Birmingham.

Tsegaye MA and Moges BA. 2014. Roles And Challenges of Secondary School Instructional Leadership for the Achievement of Student Learning: The Case of South Gondar Administrative Zone, Amhara Region, Ethiopia Asian Journal of Humanity, Art and Literature, 1, 48-69.

Turnbull, H. R., \& Turnbull, A. P. (1998). Free appropriate public education (5th ed.). Denver, CO: Love Publishing.

Wang, M. C., \& Walberg, H. J. (1988). Four fallacies of segregationism. Exceptional Children, 55, 128-137.

Will, M. C. (1986). Educating children with learning problems: A shared responsibility. Exceptional Children, 52, 411-415.

This article is is licensed under a Creative Commons AttributionNonCommercial 4.0 International License. Attribution-NonCommercial (CC BYNC) license lets others remix, tweak, and build upon work non-commercially, and although the new works must also acknowledge \& be non-commercial.

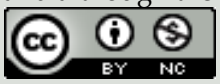

How to Cite: Mitiku W, Alemu Y and Mengsitu S. 2014. Challenges and Opportunities to Implement Inclusive Education Asian Journal of Humanity, Art and Literature, 1, 118-135.

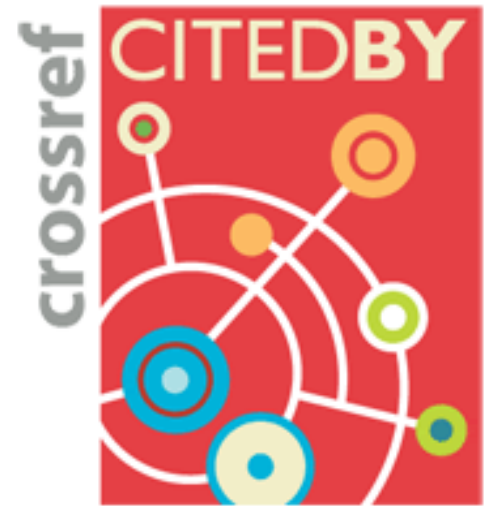




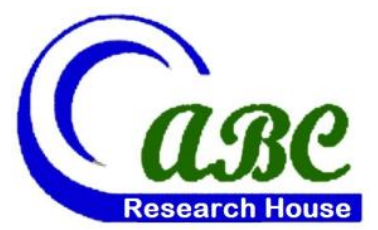

- Off Pantai Dalam, Kuala Lampur, Malaysia

- Road \# 4, Shyamoli, Dhaka-1207, Bangladesh

- 3900 Woodhue Place, Alexandria, VA 22309, USA

www.abcreorg.weebly.com / www.abcjournals.net

Asian Business Consortium (ABC) is a multi-disciplinary research, training, publishing, digital library supporting and service house. Though founded in 2010 as the Business and Computing organization of Asia, it was reconstituted as the ABC in 2011. It has been working for creating and nurturing talents in USA, Malaysia and Bangladesh since its inception. The objectives of consortium are solely centered round the welfare and humane attitude of the founders who enthusiastically took up this noble cause and materialized it with a view to promote research and educational activities for the encouragement of scholars to develop their knowledge, to publish their analysis oriented scientific researches in international Journals, books, the task of organizing workshops, seminars, conferences, training, personality development programs and allied services.

In addition to research activities, $A B C$ provides a good number of scholarships to the poor and meritorious students at various levels of education throughout the world. It plays an important role in the field of research by funding research projects and publishing the research papers. This consortium will unquestionably become the mouth-piece of the dark horses and unacknowledged scholar whose endowed and commendable contributions shall be provided an outlet keeping in mind the greater good of the larger society of the world.

$\mathrm{ABC}$ runs the following international referred journals for creating a platform to share the thoughts of professionals, scholars and academicians throughout the world.

\section{ABC Publications (ABC Journals)}

- Asian Accounting and Auditing Advancement (4A Journal)

- Asian Business Review (ABR)

- Asian Journal of Applied Sciences and Engineering (AJASE)

- Global Disclosure of Economics and Business (GDEB)

- $\quad$ ABC Journal of Advanced Research (ABC-JAR)

- International Journal of Reciprocal Symmetry and Theoretical Physics (IJRSTP)

- American Journal of Trade and Policy (AJTP)

- Asian Journal of Humanity, Art and Literature (AJHAL)

- Malaysian Journal of Medical and Biological Research (MJMBR)

- $\quad$ Asia Pacific Journal of Energy and Environment (APJEE)

- $\quad$ Engineering International (EI)

- $\quad$ ABC Research Alert (Online)

Each journal home page provides specific information for potential authors and subscribers. Open access policy, the quick review process, rich editorial boards and quality publications have already made $A B C$ Journals unique. ABC Journals are published under the direct supervisions of renowned academicians of the world.

Collaboration in Conference: $\mathrm{ABC}$ considers high-quality conference papers for publication. Please contact us for detailed information.

Collaboration in Publishing: If you like to start writing a book, propose a new journal or advertise in $A B C$ journals, please feel free to contact us. 